\title{
The Relationship Between the Digital Game Dependence and Violence Tendency Levels of High School Students
}

\author{
Battal Göldağ ${ }^{1}$ \\ ${ }^{1}$ Organized Industrial Zone Vocational School, İnönü University, Malatya, Turkey \\ Correspondence: Battal Göldağ, Organized Industrial Zone Vocational School, İnönü University, Malatya, Turkey. \\ E-mail: battal.goldag@inonu.edu.tr
}

Received: January 21, 2020

Accepted: May 3, $2020 \quad$ Online Published: July 29, 2020

doi:10.5539/ies.v13n8p118

URL: https://doi.org/10.5539/ies.v13n8p118

\begin{abstract}
The aim of this study is to investigate the relationship between digital game dependence levels and violence tendency levels of high school students. In the present research, relational survey model has been used. The population of the study consists of 9th, 10th, 11th grade students in the high schools in Battalgazi and Yeşilyurt districts of Malatya in the spring term of 2018-2019 academic year. Simple random sampling method has been used for our sample selection. Digital Game Addiction Scale (DGAS-7) was used to determine the level of digital game addiction, and Violence Tendency Scale (VRS) was used to determine the levels of violence tendency. DGAS-7 was developed by Lemmens et al. (2009). To determine the problematic digital game behaviors of adolescents between the ages of 12-18. It has been developed by Haskan and Yildirım to measure the tendency of violence among adolescents.

According to the results obtained in our research; according to the monotetic format, $4.6 \%$ of the students participating in the research were addicted to digital games, while $95.4 \%$ were not dependent. According to the polythetic format, while $21.7 \%$ is addicted to digital games, $78.3 \%$ is not addicted. There was a statistically significant difference between female and male students in terms of digital game addiction and violence tendency in favor of female students. There was also a significant difference between the levels of digital game addiction and violence tendency according to mobile phone ownership. This difference is in favor of students who do not have mobile phones. There has been a statistically significant difference between the levels of digital game addiction in favor of the students who do not have mobile internet connection, but no significant difference has been found between the levels of violence tendency. There has been a statistically significant difference between non-dependent students in terms of violent tendency levels in terms of digital game addiction in monotetic and polythetic format. The level of violence tendency of non-dependent students is lower than that of dependent students. There has been a statistically significant difference between digital game addiction levels and violence tendency levels according to the duration of digital game play. This difference is in favor of students who play less time in a day. There has been a positive and moderate relationship between digital game addiction levels and violence tendency levels.
\end{abstract}

Keywords: digital game, addiction, digital game addiction, violence, high school students

\section{Introduction}

The game is an activity taking place in every period of a person's life. Game types, rules of the games and the materials used in the games may vary from region to region, from country to country. However, with the development of the internet and the easy accessibility of the devices used, people can now play the same games in different places with the same rules in digital environment.

The game is a voluntary act or a voluntary action, accompanied by a sense of tension and joy and a sense of tension and joy, which is freely accepted, but performed within certain time and space boundaries, in accordance with strictly mandatory rules. The game is not "everyday" or a "real life", but it offers the excuse of escaping from this life and entering a temporary activity area with its own unique tendencies (Huizinga, 2013).

With the development of technology, distorted urbanization and the decrease in playgrounds, children started to play games a virtual environment not in open spaces and in parks. Now children are playing virtual games instead of playing traditional games (hide-and-seek, blind's man buff, five stones, skittless, dodgeball, etc.). These 
environments offer children the opportunity to become the person they want to be. When digital games are played uncontrollably, it also raises some problems. One of them is game addiction. Although addiction is known to cause psychological and physical harm, it is a psychological and physical deficiency in case of consumption of a chemical drug, activity or substance (Felman, 2018).

Digital game addiction is a behavioral addiction in which the biopsychosocial model is valid as in all psychiatric disorders (Şengül \& Büber, 2016). Dependent behavior is defined as a pattern of repetitive behavior that is associated with personal and social problems or increases the risk of a disease. Dependent behaviors are often subjective (loss of control). This behavior persists despite their intent to avoid or moderate use. These patterns of behavior match the detrimental effects of immediate satisfaction (short-term reward) and offset long-term costs (Marlatt, 1988). Disorders caused by addictive behaviors are visible and clinically important syndromes associated with intervention or stress to personal functions that result from repeated, rewarding behaviors other than the use of addictive substances. Disorders caused by addictive behavior include gambling disorder and gaming disorder (World Health Organization (WHO), 2019).

According to Griffiths (2005), dependencies are part of the biopsychosocial process involving contemporary psychology, biology and sociology. The biopsychosocial process leads to the development of addictions such as Internet game addiction, which includes the following components:

First, the behavior is evident (the individual is busy playing games). Second, the individual uses his behavior to change his mood (that is, the game is used to escape from reality or to create a sense of euphoria (experience of pleasure or excitement and feelings of happiness)). Third, tolerance develops (the individual needs more time to feel the same effect). Fourth, withdrawal symptoms occur upon termination of behavior (the individual feels anxious, depressed and restless when playing is prevented). Fifth, interpersonal and personal conflict develops as a result of behavior (the individual has problems with relationship, work and hobbies, and lack of achievement in deprivation). Finally, upon the end of the behavior, individual experiences recur (they start to play again) (Kuss, 2013)

According to the WHO, gaming disorder is characterized by a pattern of persistent or recurring gaming behavior (digital gaming or video gaming), which can be online (online) or offline;

1) Unbalanced control over the game (continuity, frequency, intensity, duration, finish, content)

2) Increased priority given to the game so that it gives priority over other life interests and daily activities.

3) Continuous and increasing play despite negative results. This behavior is severe enough to result in significant deterioration in personal, family, social, educational, professional or other important functional areas.

Game behavior can be continuous or intermittent and repetitive. In order for a diagnosis to be made, gaming behavior and other characteristics should normally be observed for at least 12 months (WHO, 2019).

Computer Game Addiction, developed by the American Psychiatric Association (APA, 2013) and published in May 2013 in the Diagnostic and Statistical Manual of Mental Disorders-5 (DSM-5) in the third research section under the name of personality disorders online game gaming disorders (internet gaming disorder).

DSM-5 internet game addiction criteria are taken to a large extent in substance addiction criteria and these criteria are given in Table 1 .

Table 1. DSM-5 Criteria for Internet Gaming Disorder

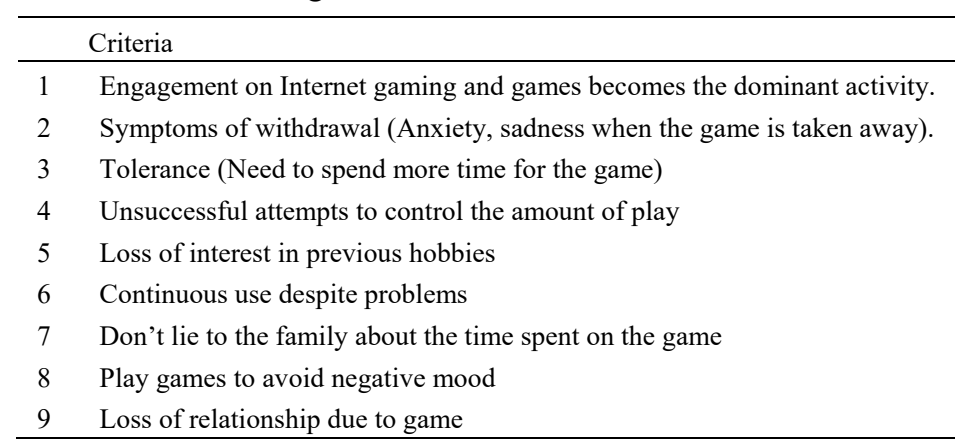

Diagnosis requires 5 or more symptoms within a 12-month period (Bean, Nelsen, Van Rooij, \& Ferguson, 2017). 
Violence: Definitions of violence seem to vary especially in terms of scope. Traditional definitions define physical actions as intent to harm. Historically, the concept of violence has only been used to refer to physical actions, and to this day, meaning has been extended to include psychological and sexual attacks (Ulu, 2016). Another distinction about violence is the definition of violence in a narrow and broad sense. Violence in a narrow sense defines physical violence. Physical violence, on the other hand, is a harsh and painful act directed against the physical integrity of people. In the broad sense, violence can be in the form of psychological violence that is felt indirectly and that physical and mental effects on human beings cannot be clearly measured (Republic Of Turkey, Ministry of National Education, 2008).

Violence comes from Latin violentia. Violentia means violence, harsh or cruel personality, power. Violare means acting violently, not knowing value, and violating the rules. These words are linked to vis. Vis, on the other hand, means power, power, authority, violence, the use of physical force, as well as quality, abundance, essence or the actual structure of something (Michaud, 1991).

The WHO defines violence as "the deliberate use of threatening or real physical force against one's self, another, a group or community." This may or may result in injury, death, psychological harm, impaired development and deprivation (Krug et al., 2002).

Games are for entertainment, educational purposes, but most of them are violent. According to content analysis, $89 \%$ of the games contain violence or violence elements (Gentile, 2003). When the literature was examined, it was found that violent computer games increased the negative effects of aggressive thinking, aggressive emotion, psychological desensitization against violence and arousal in cognitive behavior and increased aggressive emotions, thoughts and behaviors. It was stated that violent computer games can cause confusion in children's inner world and may diminish the sense of conscience (Gentile, 2003; Prot et al., 2014; Burak \& Ahmetoğlu, 2015).

\subsection{Purpose of the Research}

The aim of this study is to investigate the relationship between digital game addiction levels and violence tendency levels of high school students.

For this purpose, the following questions were sought:

1) Do high school students' levels of digital game dependence and violence tendency differ according to gender, having a mobile phone, having a mobile Internet connection, playing time, family income status and the classroom variables in which they study?

2) Is there a significant relationship between high school students' violent tendency levels and digital game addiction levels?

\section{Method}

\subsection{Research Model}

In this research, relational survey model, one of the quantitative research methods, was used. Survey models are research approaches aiming to describe a situation as it exists in the past or still. Relational screening models are research models aiming to determine the presence or degree of co-change between two and more variables (Cohen, Manion, \& Morrison, 2011).

\subsection{Population and Sample}

The population of the study is composed of the students in the 9th, 10th, 11th grades of Malatya Battalgazi and Yeşilyurt districts in the spring term of 2018-2019 academic year. Grade 12 students are not included in the program because they were preparing for the university entrance exam. Simple random sampling method has been used for sample selection. Basic information about the students is given in Table 2. 
Table 2. Descriptive statistics of students

\begin{tabular}{|c|c|c|c|}
\hline & & Frequency & Percentage \\
\hline \multirow{2}{*}{ Gender } & Female & 260 & 57.0 \\
\hline & Male & 196 & 43.0 \\
\hline \multirow{3}{*}{ Grades } & 9 & 112 & 24.6 \\
\hline & 10 & 179 & 39.3 \\
\hline & 11 & 165 & 36.2 \\
\hline \multirow{2}{*}{ Have a computer at home? } & Yes & 303 & 66.4 \\
\hline & No & 153 & 33.6 \\
\hline \multirow{2}{*}{ Have Internet Access at home? } & Yes & 287 & 62.9 \\
\hline & No & 169 & 37.1 \\
\hline \multirow{2}{*}{ Have a cell phone? } & Yes & 352 & 77.2 \\
\hline & No & 104 & 22.8 \\
\hline \multirow{2}{*}{ Have Internet Access on cell phone? } & Yes & 289 & 63.4 \\
\hline & No & 167 & 36.6 \\
\hline \multirow{4}{*}{ Game Playing duration } & 1-2 hours & 291 & 63.8 \\
\hline & 3-4 hours & 112 & 24.6 \\
\hline & 5-6 hours & 24 & 5.3 \\
\hline & 7 hours or more & 29 & 6.4 \\
\hline \multirow{5}{*}{ With which device do you play? } & Telephone & 291 & 63.8 \\
\hline & Computer & 126 & 27.6 \\
\hline & Tablet & 24 & 5.3 \\
\hline & Game console & 6 & 1.3 \\
\hline & Other & 9 & 2.0 \\
\hline \multirow{2}{*}{ Does your family control the game you play? } & Yes & 179 & 39.3 \\
\hline & No & 277 & 60.7 \\
\hline \multirow{2}{*}{ Does your family control the duration of the game you play? } & Yes & 225 & 49.3 \\
\hline & No & 231 & 50.7 \\
\hline \multirow{4}{*}{ The level of your family income } & Low & 45 & 9.9 \\
\hline & Middle & 375 & 82.2 \\
\hline & High & 36 & 7.9 \\
\hline & Total & 456 & 100 \\
\hline
\end{tabular}

$57 \%$ of the students ( 260 people) were female and $43 \%$ (196 people) were male. $24.6 \%$ (112 people) are in the ninth grade, $39.3 \%$ (179 people) are in the tenth grade, $36.2 \%$ (165 people) are in the eleventh grade. $66.4 \%$ (303 people) had computers and 33.6\% did not. 62.9\% (287 people) have fixed internet connection at home, $37.1 \%$ (169 people) do not have fixed internet connection. $77.2 \%$ (352 people) have mobile phones and $22.8 \%$ (104 people) do not have mobile phones. $63.4 \%$ (289 people) have internet connection in their mobile phone, $36.6 \%$ (167 people) do not have internet connection in their mobile phone. $63.8 \%$ (291 people) $1-2$ hours a day, $24.6 \%$ (112 people) 3-4 hours, $5.3 \%$ (24 people) $5-6$ hours and 6.4\% (29 people) play digital games for 7 hours or more. $63.8 \%$ (291 people) are digital games phone, $27.6 \%$ (126 people) computer, 5.3\% (24 people) tablet, $1.3 \%$ (6 people) game console and $2.0 \%$ (9 people) play with different devices. $39.3 \%$ (179 people) of the family controls the games they play, while $60.7 \%$ ( 277 people) does not control the games they play. The family of $49.3 \%$ ( 225 people) controls their playing time, while the family of $50.7 \%$ (231 people) does not control their playing time. $9.9 \%$ (45 people) had low income, $82.2 \%$ (375 people) had medium income, $7.9 \%$ (36 people) had high income.

\subsection{Data Collection Tools}

The Digital Game Addiction Scale has been used to identify students' addictions to digital issues, and The Tendency Scale for Violence has been used to identify levels of violence.

Digital Game Addiction Scale (DGAS-7): DGAS-7 was developed by Lemmens et al. (2009) to determine the problematic digital game behaviors of adolescents aged 12-18. Irmak and Erdoğan (2015) conducted a validity and reliability study. Alpha reliability coefficient of the Turkish scale was found to be 0.72 . In this study, Alpha reliability coefficient of the scale was found to be 0.86 . A total of 21 items are the seven-item short form of the DGAS-21, which consists of seven sub-dimensions. The scale is a five-point Likert type with a factor structure and 
scores between 1-5 $(1=$ never, 5 = always) (range: $7-35)$. Monothetic and polythetic diagnoses were used to determine whether or not he was addicted to the game according to the DGAS-7. According to the monotetic diagnosis, if a person scores seven (seven) out of seven items; if he scores at least four out of seven items according to the polythetic diagnosis, he is defined as game addict (Irmak \& Erdoğan, 2015).

The Tendency Scale for Violence (TSV): Haskan and Yıldırım (2012) were developed to measure the tendency of violence in adolescents. There is a total of 20 items in the TSV, 1 of which is reversed. The scale is of triple likert type $(3=$ always, 2 = sometimes, $1=$ never). The score that can be obtained from the TSV varies between 20 and 60. A high score means that the individual has a high tendency to violence. Alpha reliability coefficient of the scale was found to be 0.83 . In this study, Alpha reliability coefficient of the scale was found to be 0.87 .

\subsection{Data Analysis}

Statistical analysis of the data was performed by using statistical package program SPSS24.0. The normality assumption for difference analysis was examined and the coefficients of kurtosis and skewness were in the range of \pm 1 (George \& Mallery, 2016) and the data showed normal distribution characteristics. Therefore, the data were tested by using t-test (to test data from two independent samples), one-way analysis of variance test (ANOVA (to test data from three or more samples independently) for independent groups which were descriptive analyzes (mean and standard deviation) and parametric analyzes. Pearson Product Moment Correlation Analysis was used to determine the relationship between students' violent tendency levels and digital game commitment levels. Significance level was taken as $0.05(\mathrm{p}<0.05)$.

\section{Results}

In this section, digital game addiction levels of high school students, findings related to violent tendency levels, then the comparison of digital game addiction and violent tendency levels according to various variables, and the relationship between the levels of digital game addiction and violence tendency levels of high school students are given.

\subsection{Digital Game Addiction Status of Students}

The findings regarding the Digital Game Addiction Status of the students are given in Table 3.

Table 1. The conditions of Students Digital Game Addiction Cases

\begin{tabular}{ccccc}
\hline & \multicolumn{2}{c}{ Monothetic } & \multicolumn{2}{c}{ Polythetic } \\
\cline { 2 - 5 } & Frequency & Percentage & Frequency & Percentage \\
\hline Digital Game Addict & 21 & 4.6 & 99 & 21.7 \\
Not Digital Game Addict & 435 & 95.4 & 357 & 78.3 \\
Total & 456 & 100.0 & 456 & 100.0 \\
\hline
\end{tabular}

According to Table 3, 4.6\% of the students participating in the research according to the monotetic format are digital game addicts while $95.4 \%$ are not addictive. According to the polythetic format, while $21.7 \%$ are addicted to digital games, $78.3 \%$ are not addicted.

\subsection{Students' Levels of Violence Tendency}

The findings regarding the students' tendency to violence are given in Table 4.

Table 4. Levels of violence tendency of students

\begin{tabular}{cccccc}
\hline & $\mathrm{N}$ & Lowest & Highest & $\bar{X}$ & $\mathrm{~S}$ \\
\hline Violence Tendency & 456 & 20.00 & 60.00 & 35.51 & 8.16 \\
\hline
\end{tabular}

According to Table 4, the average score of the students was calculated as $35.51 \pm 8.16$. This value indicates that the students' violence tendency scores are moderate.

\subsection{Digital Game Addiction Levels and Violence Tendency Levels of Students in Terms of Gender}

Table 5 shows the level of play addiction and violence tendency of the students who participated in the study. 
Table 2. T test analysis results of students' digital game addiction levels and violence tendency levels according to gender

\begin{tabular}{|c|c|c|c|c|c|c|c|}
\hline & Gender & $\mathrm{n}$ & $\bar{x}$ & $\mathrm{~S}$ & df & $\mathrm{t}$ & $\mathrm{p}$ \\
\hline \multirow{2}{*}{ Digital Game Addiction } & Female & 260 & 11.60 & 6.061 & 454 & -6.22 & .000 \\
\hline & Male & 196 & 15.26 & 6.422 & & & \\
\hline \multirow{2}{*}{ Violence Tendency } & Female & 260 & 33.78 & 7.883 & 454 & -5.34 & .000 \\
\hline & Male & 196 & 37.79 & 7.993 & & & \\
\hline
\end{tabular}

According to Table 5, a statistically significant difference was found in favor of female students between the levels of digital game dependence $(\mathrm{t}(454)=-6.22, \mathrm{p}<0.05)$ of female and male students who participated in the study. Female students have lower levels of digital gaming addiction than male students. There was also a significant difference between male and female students' tendency to violence $(\mathrm{t}(454)=-5.34, \mathrm{p}<0.05)$. This difference is in favor of female students. Violence tendency levels of female students are lower than male students.

\subsection{Digital Game Addiction Levels and Violence Tendency Levels of Students in Terms of Their Mobile Phone Status}

Findings related to whether the game addiction and violence tendency levels of the students participating in the study differ according to their mobile phone status are given in Table 6.

Table 6. Students' digital game dependence levels and tendency levels of violence tendency levels according to the status of cell phone $t$ test analysis

\begin{tabular}{cccccccc}
\hline & Dou you have cell phone? & $\mathrm{n}$ & $\bar{x}$ & $\mathrm{~S}$ & $\mathrm{df}$ & $\mathrm{t}$ & $\mathrm{p}$ \\
\hline \multirow{2}{*}{ Digital Game Addiction } & Yes & 352 & 13.84 & 6.581 & 454 & 4.131 & .000 \\
& No & 104 & 10.91 & 5.547 & & & \\
\hline \multirow{2}{*}{ Violence Tendency } & Yes & 352 & 36.17 & 8.184 & 454 & 3.247 & .001 \\
& No & 104 & 33.25 & 7.728 & & & \\
\hline
\end{tabular}

According to Table 6, a statistically significant difference was found between the levels of digital game dependence $\left(\mathrm{t}_{(454)}=4,131, \mathrm{p}<0.05\right)$ in favor of the students who did not have a mobile phone according to their status. Students who do not have a mobile phone have lower levels of digital gaming addiction than students who have a mobile phone. There was also a significant difference between students' violent tendency levels $\left(\mathrm{t}_{(454)}=\right.$ $3.247, \mathrm{p}<0.05$ ). This difference is in favor of students who do not have mobile phones. Violence tendency levels of students who do not have mobile phones are lower than students who have mobile phones.

\subsection{Digital Game Dependence Levels and Violence Tendency Levels of Students in Terms of Their Mobile Internet Connection}

Findings related to whether the game addiction and violence tendency levels of the students participating in the study differ according to their mobile internet connection status are given in Table 7.

Table 7. Students' digital game dependence levels and violence tendency levels according to the status of mobile internet connection $t$ test analysis results

\begin{tabular}{cccccccc}
\hline \multicolumn{2}{c}{ Do you have mobile internet? } & $\mathrm{n}$ & $\bar{x}$ & $\mathrm{~S}$ & $\mathrm{df}$ & $\mathrm{t}$ & $\mathrm{p}$ \\
\hline \multirow{2}{*}{ Digital Game Addiction } & Yes & 289 & 14.11 & 6.703 & 454 & 4.135 & .000 \\
& No & 167 & 11.55 & 5.719 & & & \\
\hline \multirow{2}{*}{ Violence Tendency } & Yes & 289 & 36.00 & 8.306 & 454 & 1.734 & .084 \\
& No & 167 & 34.65 & 7.871 & & & \\
\hline
\end{tabular}

According to Table 7, a statistically significant difference was found between the levels of digital game dependence $\left(\mathrm{t}_{(454)}=4.135, \mathrm{p}<0.05\right)$ in favor of the students who did not have mobile internet connection according to their status of having mobile internet connection. Students who do not have a mobile internet connection have lower levels of digital game addiction than students who have a mobile internet connection. There was no significant difference between students' violence tendency levels $\left(t_{(454)}=1.734, p>0.05\right)$. Based on this finding, it can be said that violent tendency levels of students who do not have mobile internet connection and 
students with mobile internet connection are the same.

\subsection{Digital Game Dependence Levels and Violence Tendency Levels of Students in Terms of Their Daily Digital Game Playing Time}

Table 8 shows whether the game addiction and violence tendency levels of the students participating in the study differ according to their daily playing time.

Table 8. Results of Anova analysis of students' digital game dependence levels and violence tendency levels according to daily digital game play time

\begin{tabular}{cccccccc}
\hline & & Sum of squares & Sd & Mean Square & F & p & difference \\
\hline & Between Groups & 2396.619 & 3 & 798.873 & 21.661 & .000 & C and A \\
Digital Game Addiction & Within Group & 16669.993 & 452 & 36.881 & & & D and \\
& Total & 19066.612 & 455 & & & A. B \\
\hline \multirow{3}{*}{ Violence Tendency Level } & Between Groups & 1041.667 & 3 & 347.222 & 5.355 & .001 & D and \\
& Within Group & 29310.278 & 452 & 64.846 & & & A and B \\
& Total & 30351.945 & 455 & & & & \\
\hline
\end{tabular}

\section{A: 1-2 Hour; B: 3-4 Hour; C: 5-6 Hour; D: 7 Hour or more.}

According to Table 8 , there was a statistically significant difference between the levels of digital game dependence $\left(\mathrm{F}_{(3 ; 452)}=21.661, \mathrm{p}<0.05\right)$. According to the Tukey test to determine which groups are different, this difference is between 5-6 hours of play $\left(\bar{x}_{5-6 \text { hours }}=17.00\right)$ and 1-2 hours of play $\left(\bar{x}_{1-2 \text { hours }}=11.85\right)$ and 7 hours and more a day and between $\left(\bar{x}_{7 \text { hours and more }}=20.31\right)$ and 1-2 hours per day $\left(\bar{x}_{1-2 \text { hours }}=11.85\right)$ and 3-4 hours per day $\left(\bar{x}_{3-4 \text { hours }}=13.93\right)$.

A statistically significant difference was found between the students' tendency to violence $\left(\mathrm{F}_{(3 ; 452)}=5.355, \mathrm{p}<\right.$ $0.05)$ according to the duration of digital game play. According to Tukey test to determine which groups are different, this difference is between the students who play 7 hours and more hours $\left(\bar{x}_{7 \text { hours and more }}=41.13\right)$ and the students who play 1-2 hours a day $\left(\bar{x}_{1-2}\right.$ hours $\left.=34.95\right)$; and those who 3-4 hours between students playing $(\bar{x}$ $3-4$ hours $=35.25$ ) in a day.

\subsection{Digital Game Dependence and Violence Tendency Levels of Students in Terms of Family Income Status}

Table 9 shows whether the game addiction and violence tendency levels of the students who participated in the study differ according to their family income.

Table 9. Anova analysis results of students' digital game addiction levels and violence tendency levels according to family income status

\begin{tabular}{llllllll}
\hline & & Sum of squares & df & Mean Square & F & Sig(p) & Diffrence \\
\hline \multirow{4}{*}{ Digital Game Addiction } & Between Groups & 94.779 & 2 & 47.390 & 1.132 & .323 & None \\
& Within Group & 18971.833 & 453 & 41.880 & & & \\
& Total & 19066.612 & 455 & & & & \\
\hline \multirow{3}{*}{ Violence Tendency Level } & Between Groups & 946.118 & 2 & 473.059 & 7.288 & .001 & A and \\
& Within Group & 29405.827 & 453 & 64.914 & & & B.C \\
& Total & 30351.945 & 455 & & & & \\
\hline
\end{tabular}

A: Low; B: Middle; C: High.

According to Table 9, no statistically significant difference was found between the levels of digital game dependence $\left(\mathrm{F}_{(2 ; 453)}=1.132, \mathrm{p}>0.05\right)$ of the students who participated in the study according to their family income.

There was a significant difference between students' levels of violence tendency according to their family income $\left(\mathrm{F}_{(2 ; 453)}=7.288, \mathrm{p}<0.05\right)$. According to Tukey test which was used to determine which groups the differentiation was between, this difference is found between the students with low family income $\left(\bar{x}_{\text {low income }}=\right.$ $39.82)$ and medium familiy income $\left(\bar{x}_{\text {medium income }}=35.10\right)$; and with the students having high income $\left(\bar{x}_{\text {high income }}=\right.$ 34.36). 


\subsection{Digital Game Dependence and Violence Tendency Levels of Students in Terms of the Classes They Study}

Table 10 shows whether the game addiction and violence tendency levels of the students participating in the study differ according to the classes they study.

Table 10. The results of anova analysis of students' digital game dependence levels and violence tendency levels according to the classes they studied

\begin{tabular}{lccccccc}
\hline & & Sum of squares & Sd & Mean Square & F & Sig (p) & Difference \\
\hline & Between Groups & 459.320 & 2 & 229.660 & 5.591 & .004 & 9 and \\
Digital Game Addiction & Within Group & 18607.292 & 453 & 41.076 & & & 10.11 \\
& Total & 19066.612 & 455 & & & & \\
\hline \multirow{4}{*}{ Violence Tendency Level } & Between Groups & 590.400 & 2 & 295.200 & 4.493 & .012 & 11 and \\
& Within Group & 29761.545 & 453 & 65.699 & & & 9.10 \\
& Total & 30351.945 & 455 & & & & \\
\hline
\end{tabular}

According to Table 10, there was a statistically significant difference between the levels of digital game dependence $\left(\mathrm{F}_{(2 ; 453)}=5.591, \mathrm{p}<0.05\right)$. According to Tukey test to determine which groups are differentiation, this difference is seen between the 9 th grade students $\left(\bar{x}_{9 \text { th grade }}=14.32\right)$ and 10th grade students $\left(\bar{x}_{10 \text { th grade }}=\right.$ $13.64)$; and those students in 11th grade $\left(\bar{x}_{11 \text { th grade }}=11.89\right)$.

There was also a statistically significant difference between students' violent tendency levels $\left(\mathrm{F}_{(2 ; 453)}=4.493, \mathrm{p}\right.$ $<0.05)$. According to Tukey test to determine which groups are differentiation, this difference is between 11 th grade students $\left(\bar{x}_{11 \text { th grade }}=37.00\right)$ and 10 th grade students $\left(\bar{x}_{10 \text { th grade }}=34.82\right)$; and with those in 9 th grade $\left(\bar{x}_{9 \text { th grade }}\right.$ $=34.40$ ).

\subsection{The Relationship Between Students' Violent Tendency and Digital Game Addiction Levels}

The findings of the relationship between the levels of violence tendency and digital game addiction levels of the students who participated in the research are given in Table 11.

Table 11. Results of Pearson product moment correlation analysis to determine the relationship between digital game dependence levels and violence tendency levels

\begin{tabular}{cccc}
\hline Variable & $\mathrm{n}$ & $\mathrm{r}$ & $\mathrm{p}$ \\
\hline $\begin{array}{c}\text { Digital Game Addiction } \\
\text { Violence Tendency }\end{array}$ & 456 & .398 & .000 \\
\hline
\end{tabular}

According to Table 11, there is a positively moderately significant relationship between students' levels of digital game dependence and violence tendency $(\mathrm{r}=.398, \mathrm{p}<.01)$.

\section{Discussion}

According to the results obtained in our study, $4.6 \%$ of the students who participated in the research were digital game addicts while $95.4 \%$ were not. According to the polythetic format, while $21.7 \%$ is addicted to digital games, $78.3 \%$ is not addicted.

In the publications about game addiction, there are big differences in the world. While the rates are low in Europe, for example in the Netherlands, it is between $1.5-3 \%$ for children aged $13-16$. It was found to be high (50\% South Korea) in the Far East (Evren, 2017; Sakuma et al., 2017). Gentile et al. (2011) concluded that $9 \%$ of students were game addicts in their study in primary and secondary schools in Singapore. In their study in Germany, Grüsser et al. (2007) concluded that $11.9 \%$ of the participants were game addicts.

According to the results we obtained in our study, male students had higher levels of violence tendency than female students. Results obtained from the studies (Özgür, Yörükoğlu, \& Arabacı, 2011; Lemmens, Valkenburg, \& Peter, 2011; Kodan-Çetinkaya, 2013; Bebiş, Coşkun, \& Açıel, 2014; Yüksel, Engin, \& Turgut, 2015; Bellici, Sardoğan, \& Yılmaz, 2015; Avcı \& Yıldırım, 2015; Göldağ, 2015; Sağlam \& Twin, 2017; Balıkçı, 2018; Emiroğlu \& Bindak, 2018; Kanat, 2019) support our results. Aggressive behaviors, especially in severe forms, are more common in men. It has been suggested that less severe manifestations of severe violence in women are due to biological protection mechanisms such as greater corpus callosum volume in women, better inter-hemispheric connectivity, higher verbal skills, and earlier frontal maturation. In addition to biological differences, males are more exposed to 
environmental risk factors and central nervous systems are more sensitive to these effects (Yalçın \& Erdoğan, 2013).

Male students have higher levels of digital game addiction than female students. The results of the studies show that males are more game-dependent than females (Greenberg et al., 2010; Choo et al. 2010; Mentzoni et al., 2011; Walther, Morgenstern and Hanewinkel, 2012; Kneer, Rieger, Ivory, and Ferguson, 2014; Arslan, Kırık, Karaman, \& Çetinkaya, 2015; Ekinci, Ustun, \& Özer, 2016; Hazar, Hazar, Gökyürek, Hazar, \& Çelikbilek, 2017; Hazar, Demir, Namlı, \& Türkeli, 2017; Ekinci, Yalçın, Özer, \& Kara, 2017; Eryılmaz \& Çukurluöz, 2018; Eni, 2017; Altun \& Atasoy, 2018) and support our result.

As the family income levels of the students decrease, the levels of violence tendency increase. The reason for this may be the change in the environment and friends made with the decrease in income. Özgür, Yörükoğlu, and Arabac1 (2011) obtained the opposite result of our study, and according to the research results, as the income level of the families improved, the tendency of violence increases. In their studies, Bebiş, Coşkun, and Açıkel (2014), Özpulat (2017), Sağlam and İkiz (2017) concluded that students 'family income levels did not affect students' violence tendency levels. Digital game addiction levels do not change according to the family income level of the students. Arslan, Kırık, Karaman, and Çetinkaya (2015) also supported the results we obtained in their study. There are different results obtained from the studies. Eni (2017) concluded that digital game addiction levels increased as the total monthly income level of the family decreased. Ekinci, Yalçın, Özer, and Kara (2017) concluded that the level of game addiction increased as the family income increased.

The level of violence tendency of the students varies according to the classes they study. The level of violence tendency of 11th grade students is higher than 9th and 10th grade students. Bebiş, Coşkun, and Aç1kel (2014), Bellici, Sardoğan, and Yılmaz (2015), Sağlam and İkiz (2017) concluded that there was an increase in the tendency of violence as the level of classes increased in support of the results we obtained. The level of digital game addiction varies according to the classes of the students. As the level of education increases, the level of digital game addiction decreases. Ayhan and Çavuş (2015), Pesen and Şanlı (2018) and Balıkçı (2018) concluded that the level of digital game addiction decreased with increasing levels, while Eryılmaz and Çukurluöz (2018) concluded that there was no significant differentiation according to grade level.

The level of violence tendency varies according to the duration of the digital game play. As the daily play time of the students increases, their tendency to violence increases (Balıkçı, 2018). As students' digital game play time increases, their levels of digital game addiction increase. In their studies, Lemmens, Valkenburg, and Peter (2011), Metzoni et al. (2011), Hazar et al. (2017) and Balıkçı (2018), they have reached the conclusion that as the daily digital game time increases, the addiction increases. According to the results we obtained in our study, there is a moderately meaningful relationship between students' tendency to violence and their levels of digital game addiction. Balıç̧ (2018) concluded that there was a positive and moderate relationship between the total score of online game addiction and the total score of physical aggression, and a positive and moderate relationship between the total score of aggression.

\section{Conclusion}

In our study, regardless of the type of play the students play, a positive medium level relationship was found between game addiction and violence tendency. According to the results of the content analysis of digital games, families should be more careful when $89 \%$ of the games are considered violent. According to Bandura's social learning theory, learning takes place through observations and interactions with other people. Basically, people learn by watching others and then imitating these actions. Violence is not only with nature or character, but learned through observation and imitation, repeated as it is repeated, but extinguished as punished (Cherry, 2019; Şener \& Gökkaya, 2017). With some computer games, young people can be directed to suicide by disrupting their mental health with the conscious choice of the game producer (Aytekin, 2017). Children learn violence by observing games and imitating heroes. Rewarding violence in games, putting the child in the place of the game hero and practicing violence during the game may make the child insensitive to violence and cause hostile feelings to develop. According to the results of our study, families mostly control the play time of the children and less control the games they play. It is important that families provide guidance and options rather than prohibit children from playing. Especially the games they play, they need to check their playing time. Organizing educational seminars for families by the guidance experts of the schools on this subject will raise the awareness of the families. Seminars, conferences and events on digital games, addiction and violence should be held in schools.

\section{References}

Altun, M., \& Atasoy, M. (2018). Investigation of Digital Game Addiction of Children between 9-11 Age Groups: Kirşehir Sample. International Journal of Eurasia Social Sciences, 9(33), 1740-1757. 
APA. (2013). Diagnostic and Statistical Manual of Mental Disorders Fifth Edition Dsm-5. American Psychiatric Publishing: Washington.

Arslan, A., Kırık, A. M., Karaman, M. \& Çetinkaya, A. (2015). Lise ve Üniversite Öğrencilerinde Dijital Bağımlılık. Uluslararası Hakemli Iletişim ve Edebiyat Araştırmaları Dergisi, 8, 34-58. https://doi.org/10.17361/UHIVE.2015813153

Avcı, Ö. H., \& Yıldırım, İ. (2015). Ergenlerde Şiddet Eğiliminin Görülme Sıklı̆̆ı. Afyon Kocatepe Üniversitesi Kuramsal Ĕgitim bilim Dergisi, 8(1), 106-124. https://doi.org/10.5578/keg.7406

Ayhan, B., \& Çavuş, S. (2015). Online Game Addiction among High School Students. In C. Daba-Buzoianu, \& H. Arslan (Eds.), Contextual approaches in communication (pp. 85-93). Frankfurt: PL Academic Research.

Aytekin, G. (2017). Dijital Oyunlar ve Bireyler Üzerindeki Etkileri. Retrieved from https://www.guvenliweb.org.tr/blog-detay/dijital-oyunlar-ve-bireyler-uzerindekietkileri

Balıkçı, R. (2018). The relationship between online gaming addiction and aggressive behaviours (Master thesis, Social Sciences Institute, Fatih Sultan Mehmet University, İstanbul, Turkey). Retrieved from https://tez.yok.gov.tr/UlusalTezMerkezi/giris.jsp

Bean, A. M., Nelsen, R. K. L., Van Rooij, A. J. \& Ferguson, C. J. (2017). Video Game Addiction: The Push to Pathologize Video Games. Professional Psychology: Research and Practice, 48(5), 378-389. https://doi.org/10.1037/pro0000150

Bebiş, H., Coşkun, S., \& Açıkel, C. (2014). Bir Ortaöğretim Okulundaki Öğrencilerin Şiddet Eğilim Düzeyi ve İlişkili Faktörlerin İncelenmesi. Ege Üniversitesi Hemşirelik Fakültesi Dergisi, 30(1), 1-17.

Bellici, N., Sardoğan, M., \& Yılmaz, M. (2015). Lise öğrencilerinde okula bağlanma ve şiddet eğilimi arasindaki ilişkinin cinsiyet ve sinlf değişkenlerine göre incelenmesi. Retrieved from http://www.academia.edu/10572946/Lise_Öğrencilerinde_Okula_Bağlanma_ve_Şiddet_Eğilimi_Arasındak i_İlişkinin_Cinsiyet_ve_Sinıf_Değişkenlerine_Göre_İncelenmesi

Burak, Y., \& Ahmetoğlu, E. (2015). Bilgisayar Oyunlarının Çocukların Saldırganlık Düzeylerine Etkisinin İncelenmesi. International Periodical for the Languages, Literature and History of Turkish or Turkic, 10/11, 363-382. https://doi.org/10.7827/TurkishStudies.8430

Cheery, K. (2019). What the Bobo Doll Experiment Reveals About Kids and Aggression. Retrieved from https://www.verywellmind.com/bobo-doll-experiment-2794993

Choo, H., Gentile, D. A., Sim, T., Li, D., Khoo, A., \& Liau, A. K. (2010). Pathological Video-Gaming among Singaporean Youth. Annals Academy of Medicine Singapore, 39(11), 822-829.

Cohen, L., Manion, L. \& Morrison, K. (2011). Research methods in education (7th ed.). New York: Routledge.

Ekinci, N. E., Üstün, U. D., \& Özer, Ö. (2016). An Investigation of the Relationship between Digital Game Addiction, Gender and Regular Sport Participation. Journal of Education Culture and Society, 7(2), 298-303. https://doi.org/10.15503/jecs20162.298.303

Ekinci, N. E., Yalçın, İ., Özer, Ö., \& Kara, T. (2017). An investigation of the digital game addiction between high school students. Journal of Human Sciences, 14(4), 4989-4994. https://doi.org/10.14687/jhs.v14i4.4936

Emiroğlu, M., \& Bindak, R. (2018). Lise 9. Sınıf Öğrencilerinin Şiddet Eğilimlerinin Sosyal Problem Çözme Becerileri İle Bazı Değişkenler Açısından İncelenmesi. Social Sciences Studies Journal, 4(21), 3385-3394. https://doi.org/10.26449/sssj.765

Eni, B. (2017). Evaluation of digital game addiction and response of high school students (Master thesis, Social Sciences Institute, Haliç University, İstanbul, Turkey). Retrieved from https://tez.yok.gov.tr/UlusalTezMerkezi/giris.jsp

Eryılmaz, S., \& Çukurluöz, Ö. (2018). Lise öğrencilerinin dijital bağımlılıklarının incelenmesi: Ankara İli, Çankaya ilçesi örneği. Elektronik Sosyal Bilimler Dergisi, 17(67), 889-912. https://doi.org/10.17755/esosder.311314

Evren, C. (2017, November). Internette Oyun Oynama Bozukluğu. Sözlü bildiri, 11. Ulusal Alkol ve Madde Bağımlılı̆̆ı Kongresi, Antalya.

Felman, A. (2018). What is addiction? MedicalNewsToday. Retrieved from https://www.medicalnewstoday.com/articles/323465.php 02.208.2019

Gentile, D. A. (2003). Media Violence and Children: A Complete Guide for Parents and Professionals. United 
States of America: Praeger Publishers

Gentile, D. A., Choo, H., Liau, A., Sim, T., Li, D., Fung, D., \& Khoo, A. (2011). Pathological video game use among youths: A two-year longitudinal study. Pediatrics, 127, 319-329. https://doi.org/10.1542/peds.2010-1353

George, D., \& Mallery, P. (2016). IBM SPSS Statistics 23 Step by Step: A Simple Guide and Reference (14th ed.). New York: Routledge. https://doi.org/10.4324/9781315545899

Göldağ, B. (2015). Öğrencilerin Şiddet Eğilimi Düzeyleri ve Değer Algıları. Journal of TUBAV Science, 8(4), $1-15$.

Greenberg, B. S, Sherry, J., Lachlan, K., Lucas, K., \& Holmstrom, A. (2010). Orientations to Video Games Among Gender and Age Groups. Simulation \& Gaming, 41(2), 238-259. https://doi.org/0.1177/1046878108319930

Griffiths, M. (2005). A “components" model of addiction within a biopsychosocial framework. Journal of Substance Use, 10(4), 191-197. https://doi.org/10.1080/14659890500114359

Grüsser, S. M., Thalemann, C., \& Griffiths, M. (2007). Excessive computer gameplaying: Evidence for addiction and aggression? Cyberpsychology \& Behavior, 10(2), 290-292. https://doi.org/10.1089/cpb.2006.9956

Haskan, Ö., \& Yıldırım, İ. (2012). Şiddet Eğilimi Ölçeği’nin Geliştirilmesi. Eğitim ve Bilim, 37(163), $165-177$.

Hazar, Z., Demir, G. T., Namlı, S., \& Türkeli, A. (2017). Ortaokul Öğrencilerinin Dijital Oyun Bağımlılığı ve Fiziksel Aktivite Düzeyleri Arasındaki İlişkinin İncelenmesi. Niğde Üniversitesi Beden Eğitimi ve Spor Bilimleri Dergisi, 11(3), 320-332.

Hazar, Z., Hazar, K., Gökyürek, B., Hazar, M., \& Çelikbilek, S. (2017). Ortaokul öğrencilerinin oyunsallık, dijital oyun bağımlılı̆̆ı ve saldırganlık düzeyleri arasındaki ilişkinin çeşitli değişkenler açısından incelenmesi. Journal of Human Sciences, 14(4), 4320-4332. https://doi.org/10.14687/jhs.v14i4.5035

Huizinga, J. (2013). Homo Ludens: An Essay on the Social Function of the Game (4th ed.). (M.A. Kılıçbay). İstanbul: Ayrıntı

Irmak, A. Y., \& Erdoğan, S. (2015). Dijital Oyun Bağımlılı̆̆ı Ölçeği Türkçe formunun geçerliliği ve güvenilirliği. Anatolian Journal of Psychiatry, 16(Special issue 1), 10-18.

Kanat, S. (2019). The Relationship Between Digital Game Addiction, Communication Skills and Loneliness Perception Levels of University Students. International Education Studies, 12(11), 80-93. https://doi.org/10.5539/ies.v12n11p80

Karasar, N. (2005). Bilimsel Araştırma Yöntemi. Ankara: Nobel Printing House.

Kneer, J., Rieger, D., Ivory, J. D., \& Ferguson, C. (2014). Awareness of Risk Factors for Digital Game Addiction: Interviewing Players and Counselors. International Journal of Mental Health and Addiction, 12, 585-599. https://doi.org/10.1007/s11469-014-9489-y

Kodan-Çetinkaya, S. (2013). Üniversite Öğrencilerinin Şiddet Eğilimlerinin ve Toplumsal Cinsiyet Rollerine İlişkin Tutumlarının İncelenmesi. Nesne Psikoloji Dergisi. Nesne Journal of Psychology, 1(2), 21-43.

Krug, E. G., Dahlberg, L. L., Mercy, J. A., Zwi, A. B., \& Lozano, R. (2002). World report on violence and health. Geneva: World Health Organization. https://doi.org/10.1016/S0140-6736(02)11133-0

Kuss, D. J. (2013). Internet gaming addiction: Current perspectives. Psychology Research and Behavior Management, 6, 125-137. https://doi.org/10.2147/PRBM.S39476

Lemmens, J. S., Valkenburg, P. M., \& Peter, J. (2009). Development and Validation of a Game Addiction Scale For Adolescents. Media Psychology, 12(1), 77-95. https://doi.org/10.1080/15213260802669458

Lemmens, J. S., Valkenburg, P. M., \& Peter, J. (2011). The effects of pathological gaming on aggressive behavior. Journal of Youth and Adolescence, 40, 38-47. https://doi.org/10.1007/s10964-010-9558-x

Marlatt, G., Baer, J., Donovan, D., \& Kivlahan, D. (1988). Addictive Behaviors: Etiology and Treatment. Annual Review of Psychology, 39(1), 223-252. https://doi.org/10.1146/annurev.ps.39.020188.001255

MEB. (2008). Öğrencilerin Şiddet Algısı. Ankara: T.C. Millî Eğitim Bakanlığı Eğitimi Araştırma ve Geliştirme Dairesi Başkanlığı.

Mentzoni, R. A., Brunborg, G. S., Molde, H., Myrseth, H., Skouverøe, K. J. M., Hetland, J., \& Pallesen, P. (2011). Problematic Video Game Use: Estimated Prevalence and Associations with Mental and Physical 
Health. Cyberpsychology, Behavior, and Social-Networking, 14(10), 591-596. https://doi.org/10.1089/cyber.2010.0260

Michaud, Y. (1991). Violence (C. Muhtaroğlu). İstanbul: İletişim Publications.

Özgür, C., Yörükoğlu, G., \& Arabacı, L. B. (2011). Lise Öğrencilerinin Şiddet Algıları, Şiddet Eğilim Düzeyleri ve Etkileyen Faktörler. Psikiyatri Hemşireliği Dergisi, 2(2), 53-60.

Özpulat, F. (2017). Hemşirelik Öğrencilerinin Şiddet Eğilimleri ile Toplumsal Cinsiyet Algıları Arasındaki İlişki. Başkent Üniversitesi Sağllk Bilimleri Fakültesi Dergisi, 2(2), 151-161.

Pesen, A., \& Şanlı, T. (2018). Ortaokul Öğrencilerinde Bilgisayar Oyun Bağımlılı̆̆ Düzeyinin Çeşitli Değişkenlere Göre İncelenmesi. Online Academic Journal of Information Technology, 9(34), 105-117. https://doi.org/10.5824/1309-1581.2018.4.008.x

Prot, S., Anderson, C. A., Gentile, D. A., Brown, S. C., \& Swing, E. L. (2014). The positive and negative effects of video game play. In A. Jordan, \& D. Romer (Eds.), Media and the Well-Being of Children and Adolescents (pp. 109-128). New York: Oxford University

Sağlam, A., \& İkiz, F. E. (2017). Ortaokul Öğrencilerinin Şiddet Eğilimleri İle Okula Bağllılı Düzeyleri Arasındaki İlişkinin İncelenmesi. Illköğretim Online, 16(3), 1235-1246. https://doi.org/10.17051/ilkonline.2017.330253

Sakuma, H., Mihara, S., Nakayama, H., Miura, K., Kitayuguchi, T., Maezono, M., ... Higuchi, S. (2017). Treatment with the Self-Discovery Camp (SDiC) Improves Internet Gaming Disorder. Addictive Behaviors, 64, 357-362. https://doi.org/10.1016/J.ADDBEH.2016.06.013

Şener, N., \& Gökkaya, A. E. (2017). Günümüzde Çizgi Filmlerin Çocuk Gelişimindeki Yeri. Sosyal Bilimler Dergisi, 4(15), 380-387. https://doi.org/10.16990/SOBIDER.3815

Şengül, C., \& Büber, A. (2016). Dijital oyun bağımlılığında tanı ve tedavi. Davranışsal Bağımlılıklar. Psikiyatride Güncel, 6(3), 175-182.

Ulu, M. (2016). Kişilik ve Şiddet İlişkisi Üzerine Psikolojik Bir Araştırma. Bilimname, XXXII(3), 57-82. https://doi.org/10.21646/bilimname.2016.12

Van Rooij, A. J., van Looy, J., \& Billieux, J. (2017). Internet Gaming Disorder as a formative construct: Implications for conceptualization and measurement. Psychiatry and Clinical Neurosciences, 71, 445-458. https://doi.org/10.1111/pcn.12404

Walther, B., Morgenstern, M., \& Hanewinkel, R. (2012). Co-occurrence of addictive behaviours: Personality factors related to substance use, gambling and computer gaming. European Addiction Research, 18, 167-174. https://doi.org/10.1159/000335662

WHO. (2019). ICD-11 for Mortality and Morbidity Statistics (Version: 04/2019). Retrieved from https://icd.who.int/browse11/l-m/en\#/http://id.who.int/icd/entity/1448597234

Yalçın, Ö., \& Erdoğan, A. (2013). Şiddet ve Agresyonun Nörobiyolojik, Psikososyal ve Çevresel Nedenleri. Psikiyatride Güncel Yaklaşımlar, 5(4), 388-419. https://doi.org/10.5455/cap.20130526

Yüksel, A., Engin, E., \& Turgut, E. Ö. (2015). Hemşirelik Öğrencilerinin Şiddet Eğilimlerinin İncelenmesi. Uluslararast Sosyal Araştırmalar Dergisi, 8(41), 834-840. https://doi.org/10.17719/jisr.20154115064

\section{Copyrights}

Copyright for this article is retained by the author(s), with first publication rights granted to the journal.

This is an open-access article distributed under the terms and conditions of the Creative Commons Attribution license (http://creativecommons.org/licenses/by/4.0/). 